\title{
Activation of the P2X7 ion channel by soluble and covalently bound ligands
}

\author{
Nicole Schwarz • Ralf Fliegert • Sahil Adriouch • \\ Michel Seman • Andreas H. Guse • Friedrich Haag • \\ Friedrich Koch-Nolte
}

Received: 5 April 2008 / Accepted: 16 September 2008 /Published online: 3 March 2009

(C) The Author(s) 2009. This article is published with open access at Springerlink.com

\begin{abstract}
The homotrimeric P2X7 purinergic receptor has sparked interest because of its capacity to sense adenosine triphosphate (ATP) and nicotinamide adenine dinucleotide (NAD) released from cells and to induce calcium signaling and cell death. Here, we examine the response of arginine mutants of P2X7 to soluble and covalently bound ligands. High concentrations of ecto-ATP gate $\mathrm{P} 2 \mathrm{X} 7$ by acting as a soluble ligand and low concentrations of ecto-NAD gate P2X7 following ADP-ribosylation at R125 catalyzed by toxin-related ecto-ADP-ribosyltransferase ART2.2. R125 lies on a prominent cysteine-rich finger at the interface of adjacent receptor subunits, and ADP-ribosylation at this site likely places the common adenine nucleotide moiety into the ligand-binding pocket of $\mathrm{P} 2 \mathrm{X} 7$.
\end{abstract}

Keywords ADP-ribosyltransferases · Ecto-nucleotides · Ion channels $\cdot$ Purine receptors

Nicole Schwarz, Ralf Fliegert, and Sahil Adriouch contributed equally to this work.

N. Schwarz $\cdot$ S. Adriouch $\cdot$ F. Haag $\cdot$ F. Koch-Nolte $(\triangle)$

Institute of Immunology, Campus-Forschung 02.059,

University Medical Center Hamburg-Eppendorf,

Martinistr. 52,

20246 Hamburg, Germany

e-mail: nolte@uke.uni-hamburg.de

R. Fliegert · A. H. Guse

Institute of Biochemistry and Molecular Biology I: Cellular Signal

Transduction, University Medical Center Hamburg-Eppendorf,

20246 Hamburg, Germany

S. Adriouch $\cdot$ M. Seman

Inserm U905, Faculté de médicine et de pharmacie,

Université de Rouen,

76183 Rouen, France

\section{Introduction}

Nicotinamide adenine dinucleotide (NAD) and adenosine triphosphate (ATP) are the universal currencies of energy metabolism in all kingdoms of life. Following their release from cells, ATP and NAD can function as extracellular signaling molecules [1-3]. The extracellular actions of ATP are mediated through ionotropic P2X and metabotropic P2Y purinergic receptors [4-7]. Extracellular NAD serves as a substrate for cell surface ADP-ribosyltransferases (ARTs) that catalyze the post-translational modification of membrane proteins by ADP-ribose [8-10]. The concentrations of extracellular ATP and NAD are controlled by ATP- and NAD-hydrolyzing ecto-enzymes such as CD39 and CD38 [11, 12].

Mammalian cell surface ARTs transfer the ADP-ribose moiety from NAD onto arginine residues on secreted and membrane proteins including defensin 1 , integrins, and the P2X7 receptor [13-15]. These mammalian ARTs are closely related in structure and function to bacterial toxin ARTs like the $\mathrm{C} 2$ and $\mathrm{C} 3$ toxins of Clostridium botulinum [16-20]. ADP-ribosylation can either inactivate the function of the target protein as in the case of actin and elongation factor 2 [21, 22], or activate target protein function as in the case of the $\mathrm{P} 2 \mathrm{X} 7$ receptor $[15,23]$.

Among purinergic receptors, $\mathrm{P} 2 \mathrm{X} 7$ is widely expressed on immune cells and plays a crucial role in the processing and release of the leader-less cytokines IL- $1 \beta$ and IL-18 [24-29]. P2X7 has been implicated in the activation of the inflammosome, the killing of intracellular microorganisms by macrophages, apoptosis of $\mathrm{T}$ cells, cell fusion, and shedding of the CD62L homing receptor [15, 30-38].

Activation of P2X7 either by high concentrations of ecto-ATP or by ADP-ribosylation induces P2X7 to form a nonselective cation channel, allowing influx of calcium, followed rapidly by exposure of phosphatidylserine on the outer leaflet of the plasma membrane [15, 39-42]. 
Prolonged activation of $\mathrm{P} 2 \mathrm{X} 7$ induces the formation of a nonselective pore, recently identified as pannexin 1 , that allows the passage of large DNA-staining dyes such as YOPRO-1, followed by membrane blebbing, mitochondrial dysfunctioning, DNA fragmentation, release of lactate dehydrogenase, and cell death [15, 40, 41, 43-45].

Like other $\mathrm{P} 2 \mathrm{X}$ receptors, $\mathrm{P} 2 \mathrm{X} 7$ is thought to form trimers [46]. Each subunit has two transmembrane regions (Tm1 and Tm2) and cytosolic N- and C-termini [5-7]. The extracellular ligand-binding domain contains approximately 280 amino acid residues (aa 47-329), including ten conserved cysteine residues that are probably engaged in intrachain disulfide bonding $[47,48]$. No 3D structure is yet available for any of the $\mathrm{P} 2 \mathrm{X}$ purinergic receptors, but modern prediction programs such as PSI-PRED [49] can pinpoint potential secondary structures and provide insight into the local structural context of amino acid residues [23].

The extracellular domain of P2X7 contains 11 arginine residues that are strictly conserved in mouse, rat, and human P2X7 (Fig. 1). Residues R125 and R151 lie on the side and at the tip of a conspicuous cysteine-rich "finger" that is connected by three closely spaced disulfide bridges. Residue R206 is flanked by two potential N-linked glycosylation sites. Residues R307 and R316 are located in a $\beta$-stranded region upstream of $\mathrm{Tm} 2$. The other conserved arginine residues lie outside of well-defined secondary structure units, consistent with a location in loops on the surface of the protein, as would be expected for charged amino acid residues.

\section{Results and discussion}

Lysine substitutions at R206, R276, and R277 result in enhanced ATP sensitivity, and lysine substitution at R294 results in loss of ATP sensitivity

In order to explore the potential functional significance of the conserved arginine residues in the extracellular domain of P2X7 and in order to identify the target residue(s) for ADP-ribosylation, we analyzed the effects of substituting each of these arginines for lysine or alanine on expression and function of P2X7 in transfected human embryonal kidney (HEK) cells. Cell surface expression levels were assessed $20 \mathrm{~h}$ post-transfection by flow cytometry using three different fluorochrome-conjugated antibodies that recognize $\mathrm{P} 2 \mathrm{X} 7$ in native conformation [15, 50]. All arginine to lysine mutants except for mutant R307K were clearly detectable on the cell surface [23]. Other conservative substitutions of this residue resulted in low expression levels, indicating that an arginine at this position is required for proper expression and/or stability of the protein. Mutants $\mathrm{R} 151 \mathrm{~K}$ and R151A were detectable with monoclonal antibody Hano43 but lost reactivity with mAb Hano44 and with the anti-P2X7 serum $\mathrm{K} 1 \mathrm{G}$, consistent with the notion that the cysteine-rich region containing R151 forms a fingerlike structure accessible to antibodies [23].

Using a sensitive live cell imaging technique, we assessed calcium responses and membrane blebbing of HEK cells attached to cover slips $20 \mathrm{~h}$ after transfection with wild-type and mutant P2X7 (Fig. 2). When cells were perfused for 3-min periods with increasing doses of ATP, we observed small transient responses in untransfected and mock-transfected HEK cells likely mediated by metabotropic P2Y receptors (panel 1). Typically, these transient responses were induced at low doses of ATP $(10 \mu \mathrm{M}$, and in some cells even at $1 \mu \mathrm{M})$. Although ATP mediates a P2X7-independent response in HEK cells, the responses mediated by $\mathrm{P} 2 \mathrm{X} 7$ could be clearly distinguished from the former: cells expressing wild-type P2X7 showed a strong sustained response to $1 \mathrm{mM}$ ATP, which subsided only after removal of ATP (panel 2). Most P2X7 mutants showed responses similar to wild-type P2X7(panels 3-6, 8, and 13), whereas cells expressing R294K and R307K did not show any responses besides the transient responses also seen in mock-transfected cells (panels 11, 12). Strikingly, cells expressing $\mathrm{R} 276 \mathrm{~K}$ or $\mathrm{R} 277 \mathrm{~K}$ showed sustained responses already to $100 \mu \mathrm{M}$ ATP. Moreover, in these cells, calcium responses were maintained at elevated levels during washout of ATP (panels 9 and 10). Similarly, HEK cells expressing R206K initiated sustained calcium responses already to $100 \mu \mathrm{M}$ ATP, albeit with a slight delay (panel 7).

Similar results were obtained using florescence-activated cell sorting (FACS)-based assays for ATP-induced changes in forward and side scatter (Fig. 3) by HEK cells harvested $20 \mathrm{~h}$ after transfection. Six mutants-R53K, R125K, R151K, R178K, R230K, and R316K-displayed ATP potencies in these assays similar to wild-type P2X7 $\left(\mathrm{EC}_{50}\right.$ 150-300 $\mu \mathrm{M}$ ) (Fig. 3b, panel 2). Mutant R294K, which is expressed on the cell surface, and mutant R307K, which is not expressed on the cell surface completely lacked any detectable response to ATP (Fig. 3a, panel 2 and Fig. 3b, panel 1). The three mutants, R206K, R276K, and R277K, again showed ATP potencies that were enhanced five- to 20-fold compared to wild-type P2X7 (EC 50 7.5-30 $\mu \mathrm{M})$ (Fig. 3b, panel 3). Similar results were obtained for ATPinduced exposure of phosphatidylserine and formation of pores permeable to the DNA staining dye YO-PRO-1 (data not shown and [23]).

These results underscore the functional importance of residues R294 and R307. The finding that mutant R294K was expressed at the cell surface at wild-type levels, but did not show any detectable responses to ATP or NAD, is in accord with previous studies reporting loss of function upon mutation of the corresponding residues to alanine or lysine in human P2X1 (R292), rat P2X2 (R291), and mouse P2X7 
Fig. 1 Schematic diagram of the functional consequences following substitution of the conserved arginine residues in the ectodomain of mouse P2X7. The connectivity of cysteine residues (in red) corresponds to that proposed for $\mathrm{P} 2 \mathrm{X} 1$ and P2X2 [6]. The conserved arginine $(R)$ residues in the ectodomain are indicated by yellow diamonds, the natural allelic polymorphism in the cytosolic domain [70] that distinguishes $\mathrm{C} 57 \mathrm{BL} / 6$ mice from wild-type mice is indicated by a pink circle. Potential glycosylation sites are indicated by green triangles and predicted $\beta$-strands by blue arrows. The sequences in the alignment of mouse, rat, and human $\mathrm{P} 2 \mathrm{X} 7$ are truncated five residues downstream of Tm2. Secondary structures predicted with PSIPRED [49] are indicated above the alignment ( $H$ helix; $E$ extended $\beta$-strand; $C$ coil, unstructured). Structure units with a confidence $>8$ are highlighted in blue. Identical amino acid residues are indicated by asterisks, strongly and weakly conserved residues by colons and periods, respectively. Predicted transmembrane domains and conserved cysteine residues are in red, potential $\mathrm{N}$-linked glycosylation sites are in green. The 11 conserved arginine residues in the ectodomain are highlighted in yellow and their positions in residue number (for mouse P2X7) are indicated above the alignment loss of

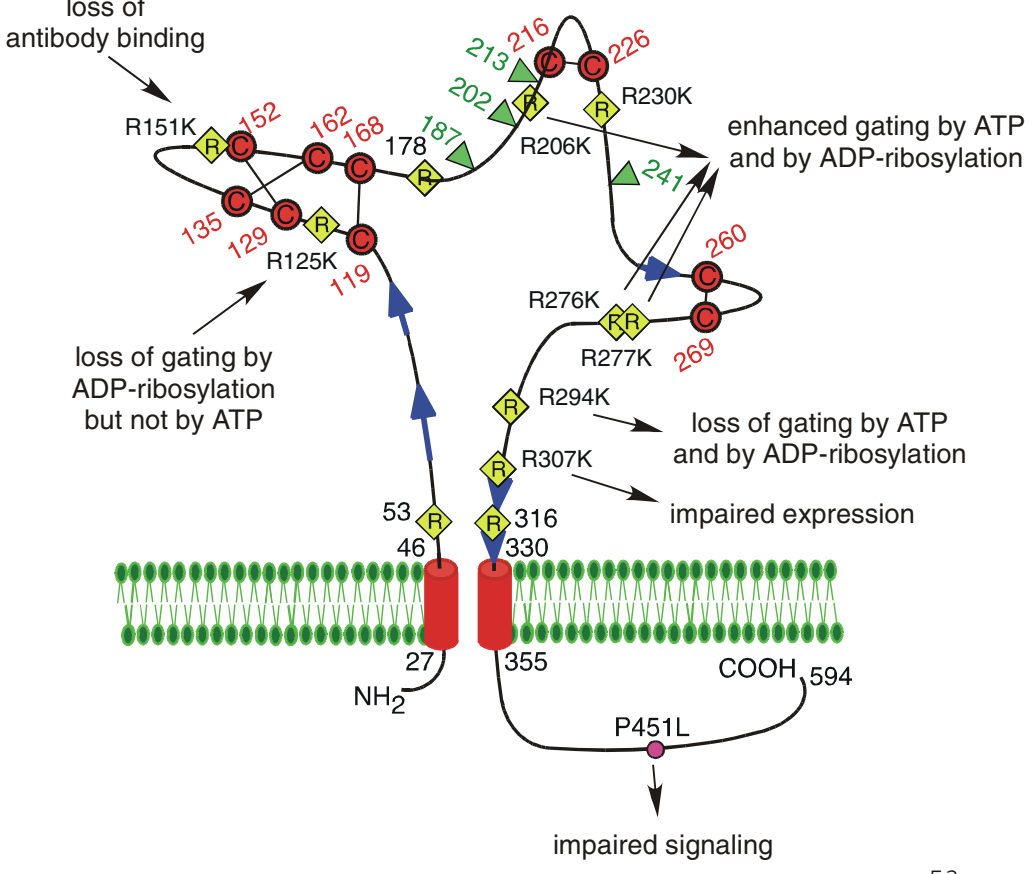

53

Conf: $\quad 961221013320356308997311022245788888886401021232321011676237$

Pred: CCCHHHHHHHHCCCCCEEEEEECCEEEHHHHHHHHHHHHHHHHHHEECCCCCCCCCCCEE mmP2X7 MPACCSWNDVFQYETNKVTRIQSTNYGTVKWVLHMIVFSYISFALVSDKLYQRKEPVISS InP2X7 MPACCSWNDVFQYETNKVTRIQSVNYGTIKWILHMTVFSYVSFALMSDKLYQRKEPLISS hSP2X7 MPACCSCSDVFQYETNKVTRIQSMNYGTIKWFFHVIIFSYVCFALVSDKLYQRKEPVISS $* * * * * * . * * * * * * * * * * * * * * * * * *: * * .: *:: * * *: . * * *: * * * * * * * * * *: * * *$

Conf: 999998888861233212321000100264111214788768997621570560016465 Pred: EEEEEEEEEEEECCCCCCCCCHHHHHCCCCCCEEECCCCCEEEEEEEEEEECCEECCCCC mmP2X7 VHTKVKGIAEVTENVTEGGVTKLGHSIFDTADYTFPLQGNSFFVMTNYVKSEGQVQTLCP InP2X7 VHTKVKGVAEVTENVTEGGVTKLVHGIFDTADYTLPLQGNSFFVMTNYLKSEGQEQKLCP hSP2X7 VHTKVKGIAEVKEEIVENGVKKLVHSVFDTADYTFPLQGNSFFVMTNFLKTEGQEQRLCP

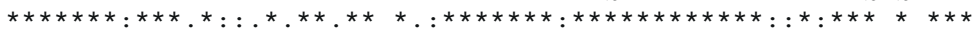
125 151 178

Conf: $\quad 677877667754678888455688961101377168871202566532788765567640$ Pred: CCCCCCCCCCCCCCCCCCCCCCCCCCEEEEEEEECCCCCCCEEEEEECCCCCCCCCCCCC mmP2X7 EYPRRGAOCSSDRRCKKGWMDPOSKGIOTGRCVPYDKTRKTCEVSAWCPTEEEKEAPRPA InP2X7 EYPSRGKQCHSDQGCIKGWMDPQSKGIQTGRCIPYDQKRKTCEIFAWCPAEEGKEAPRPA hSP2X7 EYPTRRTLCSSDRGCKKGWMDPQSKGIQTGRCVVYEGNQKTCEVSAWCPIEAVEEAPRPA

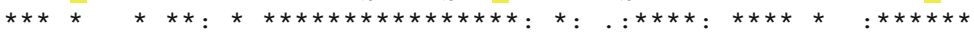
206 230

Conf: $\quad 122057764650453014652651577676766534327765753440244157654278$ Pred: HHHCCCCCEEECCCCCCCCCCCCCCCCCCCCCCCCEEECCCCCCCCCHHHHHHHHHHHCC mmP2X7 LLRSAENFTVLIKNNIHFPGHNYTTRNILPTMNGSCTFHKAWDPQCSIFRLGDIFQEAGE InP2X7 LLRSAENFTVLIKNNIDFPGHNYTTRNILPGMNISCTFHKTWNPQCPIFRLGDIFQEIGE hSP2X7 LLNSAENFTVLIKNNIDFPGHNYTTRNILPGLNITCTFHKTQNPQCPIFRLGDIFRETGD $* * . * * * * * * * * * * * * * . * * * * * * * * * * * *::^{*}: * * * * *:: * * * . * * * * * * * *: * *:$

276277 294

Conf: $\quad 840412342588899850258887635686641330278877544220102113201211$ Pred: CHHHEEEEEEEEEEEEEECCCCCCCCCCCCCEEECCCCCCCCCCEECEEECCCCEEEH mmP2X7 NFTEVAVQGGIMGIEIYWDCNLDSWSHHCRPRYSFRRLDDKNMDESFVPGYNFRYAKYYK InP2X7 NFTEVAVQGGIMGIEIYWDCNLDSWSHRCQPKYSFRRLDDKYTNESLFPGYNFRYAKYYK hSP2X7 NFSDVAIQGGIMGIEIYWDCNLDRWFHHCRPKYSFRRLDDKTTNVSLYPGYNFRYAKYYK $* *:: * *: * * * * * * * * * * * * * * * *: *: *: * * * * * * * *:: *: * * * * * * * * * * *$ 307 316

Conf: $\quad 068404578888517999998268763004788888888887753689999999986200$

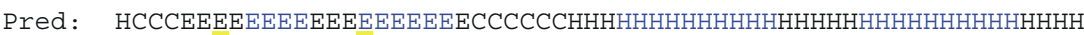
mmP2X7 ENNVEKRTLIKAFGIRFDILVFGTGGKFDIIQLVVYIGSTLSYFGLATVCIDLLINTYSS rnP2X7 ENGMEKRTLIKAFGVRFDILVFGTGGKFDI IQLVVYIGSTLSYFGLATVCIDLI INTYAS hSP2X7 ENNVEKRTLIKVFGIRFDILVFGTGGKFDIIQLVVYIGSTLSYFGLAAVFIDFLIDTYSS

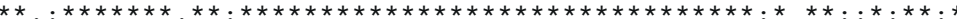


Fig. 2 Potency of ATP to induce calcium flux in HEK cells transiently transfected with P2X7 variants. HEK cells were co-transfected with expression constructs for mRFP and wild-type or mutant P2X7 receptors. Twenty hours posttransfection, cells were loaded with the calcium-sensitive fluorochrome Fura-2 before live cell imaging by fluorescence microscopy. Images were captured every $5 \mathrm{~s}$. At the indicated times, the perfusion buffer $\left(37^{\circ} \mathrm{C}\right)$ was changed to subject cells to increasing doses of ATP. Ratio images $(340 / 380 \mathrm{~nm})$ were constructed pixel-by-pixel and single cell tracings were captured using the Openlab software. Gray lines show single cell tracings, red lines the calculated mean

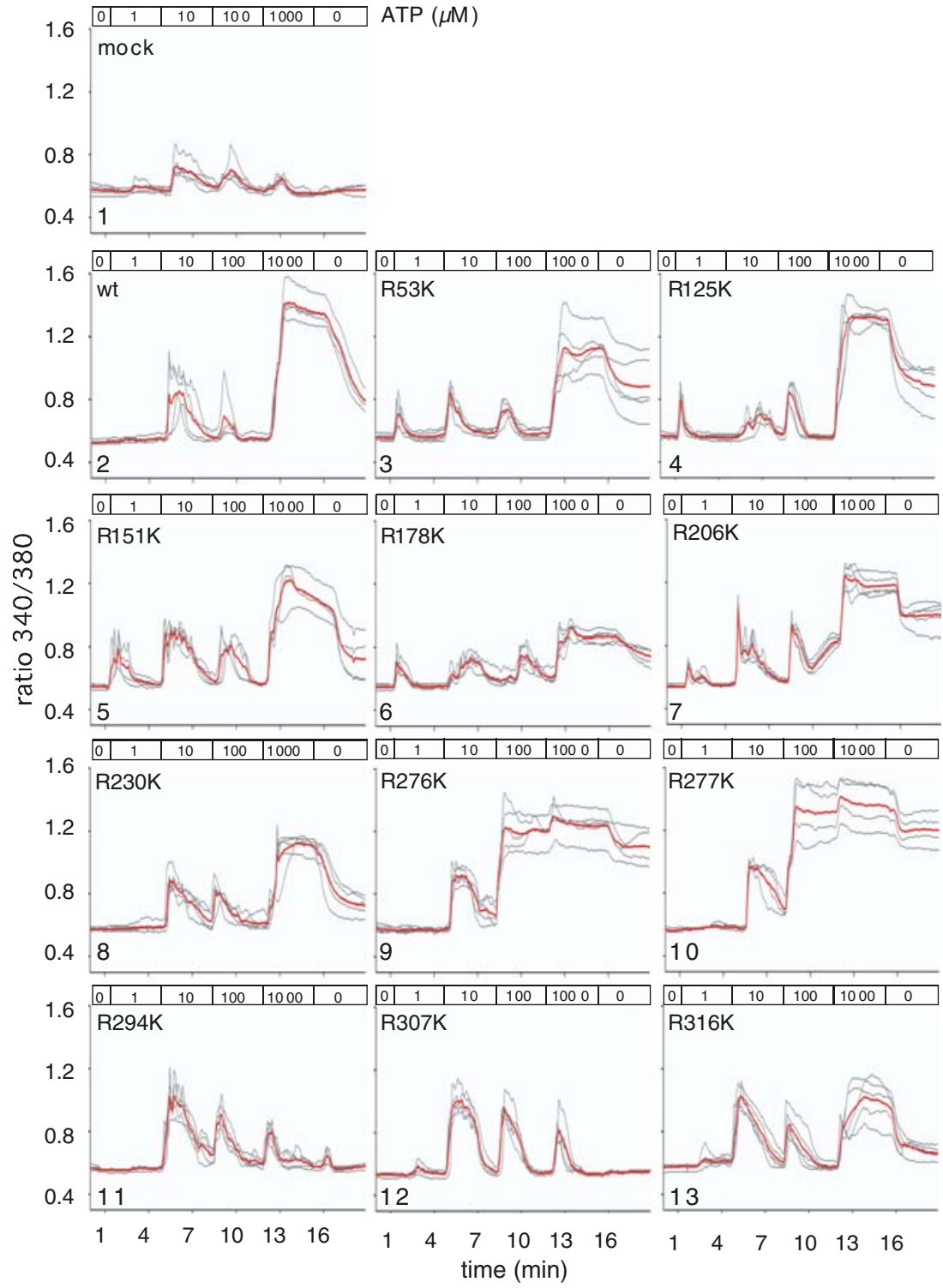

[50-52]. R294 forms part of a contiguous asparaginephenylalanine-arginine (NFR) motif that has been proposed to coordinate binding of the adenine and ribose moieties [6]. R307, on the other hand, seems to be important for proper folding and/or stability of the receptor, since mutation of this residue to any of five other residues tested (A, K, Q, E, and $\mathrm{H}$ ) had a strong negative impact on cell surface expression. A natural allelic variant, R307Q, has been described previously for human P2X7 [53], which also did not show any detectable ATP response.

Lysine substitutions at R206, R276, and R277 result in enhanced sensitivity to gating by ADP-ribosylation

We further assayed whether activation of P2X7 by ADPribosylation can be observed in HEK cells co-transfected with ART2 and each of the 11 P2X7 arginine mutants
(Fig. 4). Live cell calcium imaging experiments in which cells were perfused for 3-min periods with increasing doses of NAD revealed a small transient response to high NAD concentrations $(250 \mu \mathrm{M})$ in untransfected and mocktransfected HEK cells, possibly mediated by the metabotropic P2Y11 receptor [54]. Strong sustained responses to 100 -fold lower concentrations of NAD $(2.5 \mu \mathrm{M})$ were detected in the case of cells co-transfected with ART2.2 and mutants R206K, R276K, or R277K (Fig. 4, panels 7, 9, 10), i.e., the same mutants that had shown dramatically enhanced sensitivity to ATP in the previous assays (Fig. 2, panels 7, 9, 10 and Fig. 3b, panel 3). Further, HEK cells cotransfected with ART2.2 and these mutants responded with exposure of phosphatidylserine and uptake of YO-PRO-1 in response to NAD (data not shown). Interestingly, however, cells co-transfected with ART2.2 and wild-type P2X7 or P2X7 mutants with wild-type-like sensitivities to ATP did 
Fig. 3 Potency of ATP to induce changes in forward and side scatter of HEK cells transiently transfected with $\mathrm{P} 2 \mathrm{X} 7$ variants. HEK cells were transfected with expression constructs for wild-type or mutant P2X7 receptors. Twenty hours post-transfection, cells were harvested by mild trypsinization and cells were incubated for $60 \mathrm{~min}$ in the absence or presence of the indicated concentrations of ATP before FACS analyses.

a Contour plots illustrating the changes in cell size (forward scatter, FSC) and cell granularity (side scatter, $S S C$ ) induced by $1 \mathrm{mM}$ ATP. b Dose-response curves illustrating the mean FSC of HEK cells treated as in (a) as a function of the concentration of ATP

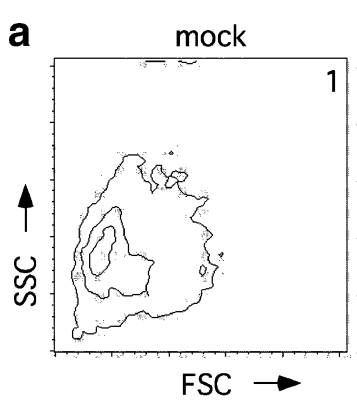

b

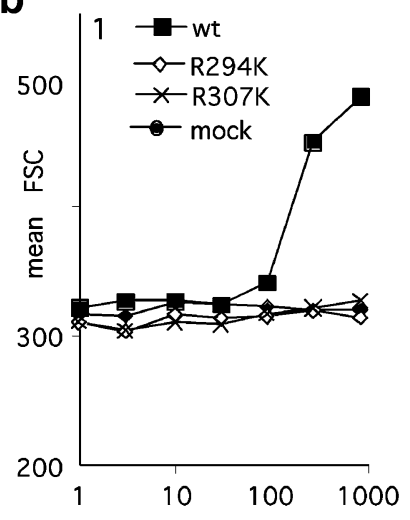

R294K
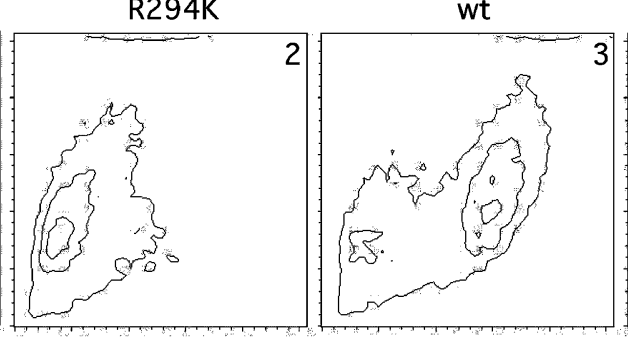

3

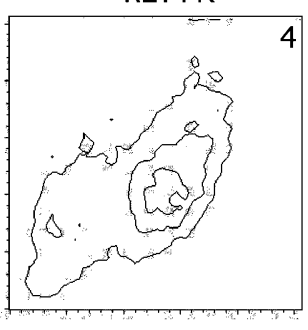

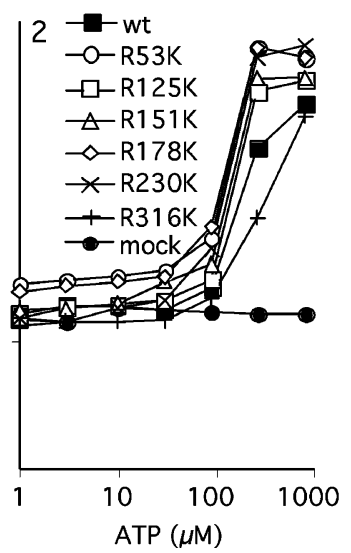

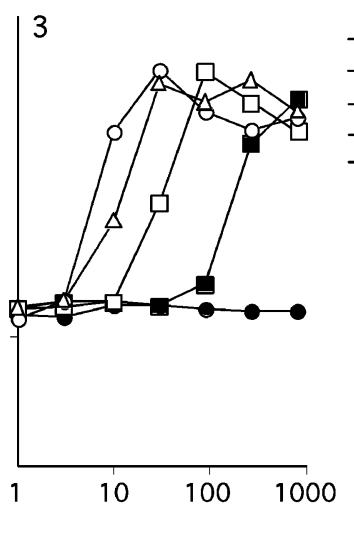

not show any detectable responses, even to saturating concentrations of NAD (panels 2-6, 8, 13 in Figs. 2 and 4).

When comparing the responses of $\mathrm{P} 2 \mathrm{X} 7$ to the soluble ligand ATP vs. the immobilized ligand ADP-ribose (generated by ART2.2 upon exposure of cells to NAD), several points are worth noting: Firstly, much lower concentrations of NAD $(2.5 \mu \mathrm{M})$ than ATP $(100 \mu \mathrm{M})$ are required to activate the gain-of-function mutants R206K, R276K, and R277K. A similar difference in the sensitivity of wild-type P2X7 to activation by ATP vs. NAD has been noted previously for primary $\mathrm{T}$ cells [15]. This much higher sensitivity to low concentrations of NAD vs. ATP most likely reflects a higher stability and consequently higher local concentration of a covalently bound vs. soluble ligand. Secondly, and in accord with this notion, calcium signals subside more slowly during washout of saturating concentrations of NAD than ATP (panels 7, 9, and 10 in Fig. 2 vs. Fig. 4). Similarly, PS exposure by primary T cells induced by short pulse treatments of ATP was readily reversed but the effects induced by pulse treatments with NAD were not [15]. Thirdly, in ART2.2 co-transfected HEK cells, neither wild-type P2X7 nor any of the six mutants with wild-type-like responses to ATP showed any detectable responses to NAD (Fig. 4, panels 2-6, 8, and 13), even at concentrations far above the levels required for saturating ADP-ribosylation of proteins on the HEK cell surface. Most likely, the different sensitivities of P2X7 to activation by ADP-ribosylation in HEK cells vs. primary $\mathrm{T}$ cells reflect differences in these cells in proteins and/or lipids in the plasma membrane available for interaction with P2X7 [55, 56]. Indeed, even different subsets of $\mathrm{T}$ cells evidently differ in their sensitivity to $\mathrm{P} 2 \mathrm{X} 7$ activation, with regulatory $\mathrm{T}$ cells being particularly sensitive [57].

ADP-ribosylation at R125 in the cysteine-rich finger provides a ligand for the binding site while ADP-ribosylation at R133 does not

Analysis of radiolabeling of P2X7 mutants in ART2.2 cotransfected HEK cells using radioactive $\left[{ }^{32} \mathrm{P}\right]-\mathrm{NAD}$ as substrate allowed us to identify R125 and the nearby nonconserved residue R133 as the sole targets for ADPribosylation in P2X7 [23]. Both of these residues are located in a prominent finger-like cysteine-rich region (Fig. 1). The NAD-mediated activation of P2X7 in HEK cells cotransfected with the gain-of-function mutant R276K and ART2.2 allowed us to directly assess whether ADPribosylation of $\mathrm{P} 2 \mathrm{X} 7$ itself or ADP-ribosylation of other membrane proteins was responsible for gating of P2X7 [23]. Replacement of R125 by lysine in R276K abolished responses to NAD, while replacement of R133 by lysine did not. Importantly, substitution of residues R125 or R133 with lysine, either alone or in combination, did not alter the sensitivity to ATP, indicating that the ligand-binding site itself was not affected by these substitutions. These results demonstrated that ADP-ribosylation at R125 gates P2X7, whereas ADP-ribosylation at R133 does not [23]. The observation that the R125K mutant could not be activated 
Fig. 4 Potency of ADPribosylation to induce calcium flux in HEK cells transiently transfected with $\mathrm{P} 2 \mathrm{X} 7$ variants. HEK cells were co-transfected with expression constructs for mRFP, ART2.2, and wild-type or mutant P2X7 receptors. Twenty hours posttransfection, cells were loaded with the calcium-sensitive fluorochrome Fura-2 before live cell imaging by fluorescence microscopy as in Fig. 2. At the indicated times, the perfusion buffer $\left(37^{\circ} \mathrm{C}\right)$ was changed to subject cells to increasing doses of NAD. Gray lines show single cell tracings, red lines the calculated mean

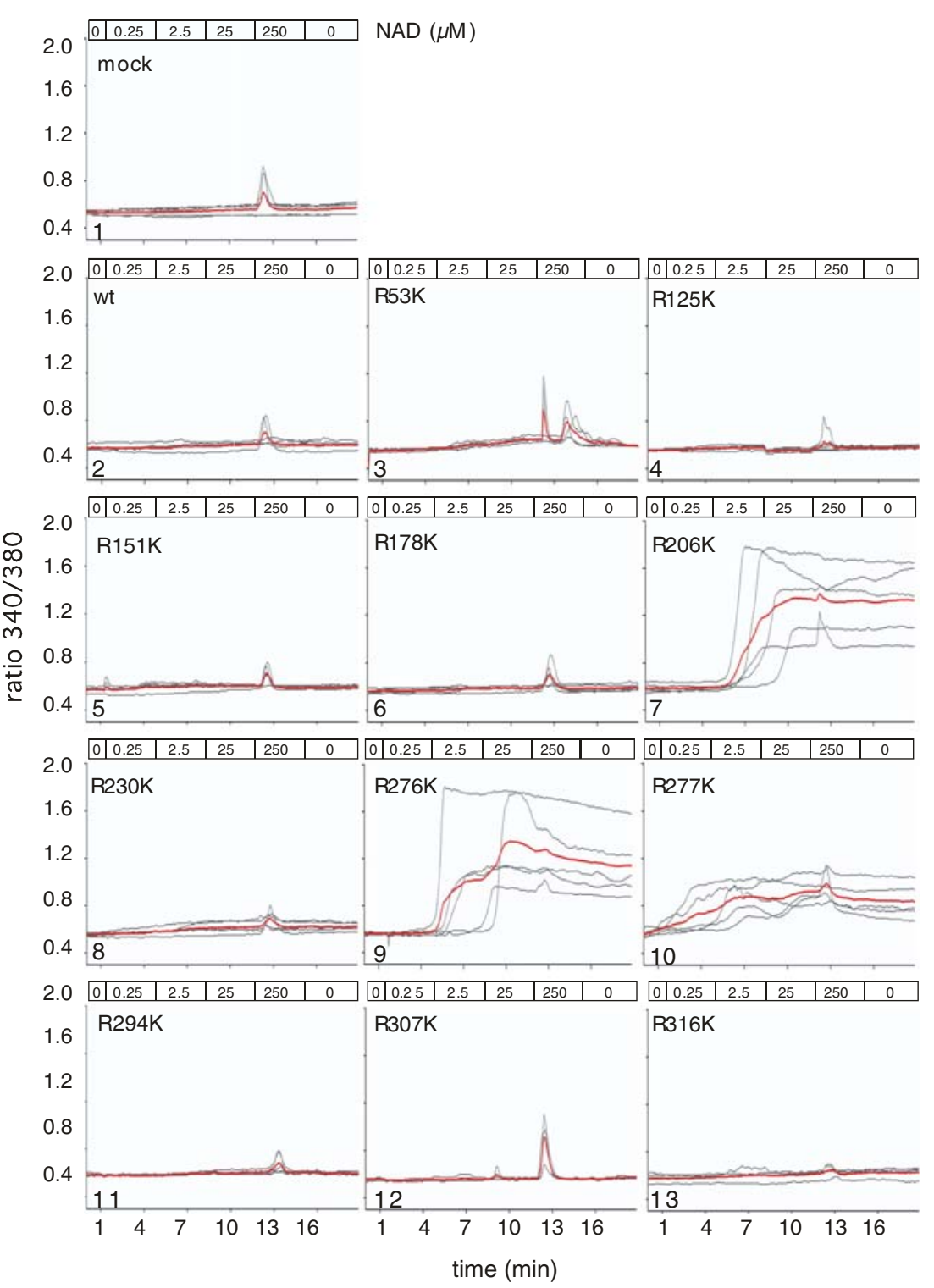

by ADP-ribose groups bound either to R133 or attached to other target proteins on the cell surface effectively rules out the model proposed by Kawamura and coworkers, in which P2X7 was proposed to be activated by ADP-ribosyl groups presented on neighboring ADP-ribosylated proteins [35].

In analogy to glutamate and nicotinic receptors, it has been proposed that the ligand-binding site of P2X purinergic receptors is located at the interface of two adjacent receptor subunits [5, 6]. Our model for the activation of $\mathrm{P} 2 \mathrm{X} 7$ by ADP-ribosylation is in line with this notion (Fig. 5). We propose that the ADP-ribose moiety covalently attached to R125 provides a ligand that fits into the binding site between two adjacent P2X7 subunits. This model accounts for the resistance of $\mathrm{P} 2 \mathrm{X} 7$ to activation by covalently linked ethenoADP-ribose and other ADP-ribose analogues carrying modifications of the adenosine moiety, as these analogues would not be expected to fit into the ligand-binding site [15].
Moreover, our model accounts for the finding that ADPribosylation at the second target site, R133, does not activate P2X7, as the ADP-ribose unit attached to R133 would be out of reach of the ligand-binding site. Further, our model is in accord with the notion that residue R125 lies at the interface of two neighboring subunits. This is consistent with recent findings for the corresponding histidine residue in $\mathrm{P} 2 \mathrm{X} 2$, H120 [58]. A disulfide bond was formed between adjacent P2X2 subunits when this residue and residue H213 (S215 in $\mathrm{P} 2 \mathrm{X} 7$ ) were mutated to cysteine.

Our results further indicate that the cysteine-rich region plays an important functional role and may form an exposed finger-like structure. This region is accessible to ART2.2 (i.e., can be ADP-ribosylated at R125 and R133) as well as to antibodies, with residue R151 at the tip of the finger-forming part of the epitope recognized by both, the monoclonal rat antibody Hano43 and by the polyclonal 
Fig. 5 Model for the activation of P2X7 by ADP-ribosylation at R125. a Schematic diagram of the trimeric $\mathrm{P} 2 \mathrm{X} 7$ receptor complex in open conformation following binding of ATP at the interface of two adjacent subunits. b ADP-ribosylation at R125 places the attached ADPribose in the ligand-binding site, inducing the open conformation c ADP-ribosylation at residue R133 places the attached ADPribose out of reach of the binding site. d Schematic diagrams of the soluble ligand ATP and of ADP-ribose in covalent linkage to R125. Residues K64 and K311 may interact with the negatively charged phosphate groups, residues F293 and R294 with the adenine-ribose moiety $[6,76]$
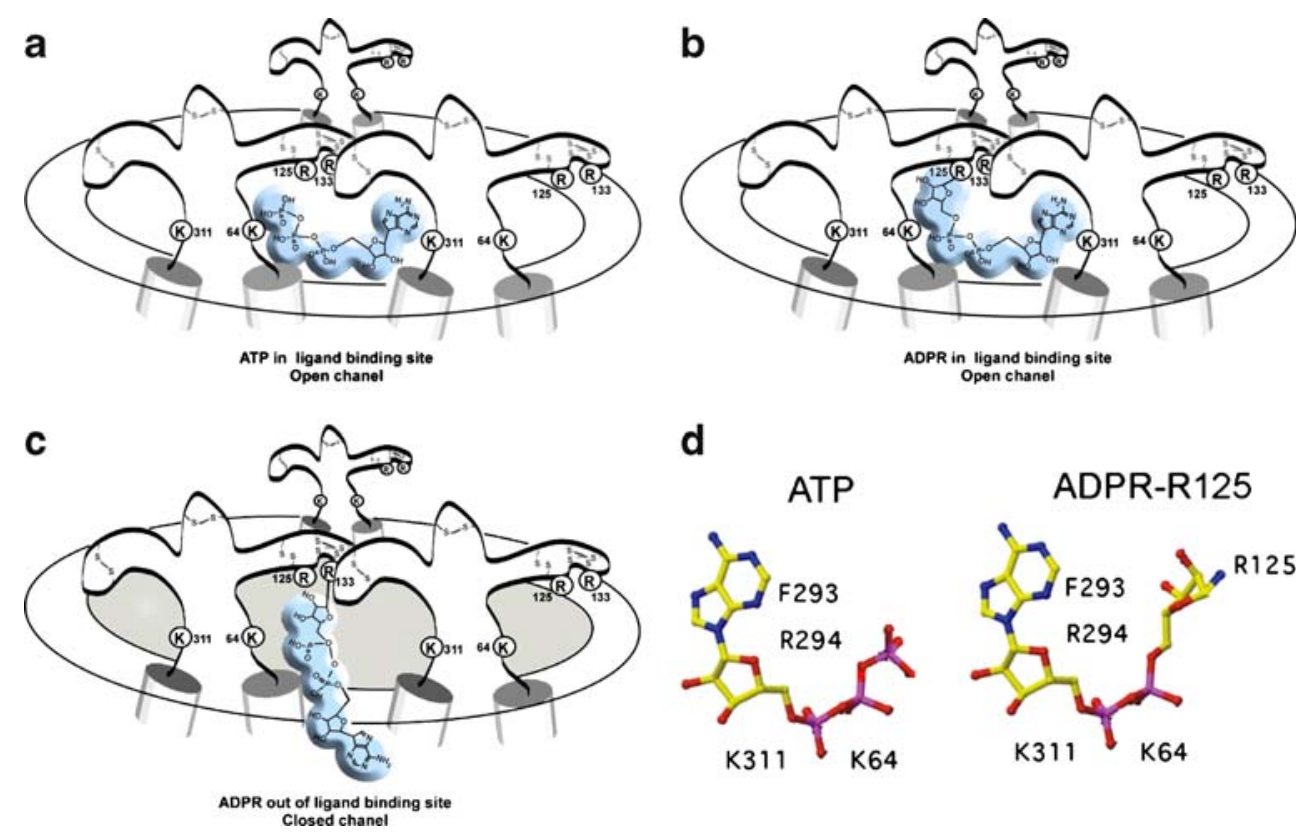

d
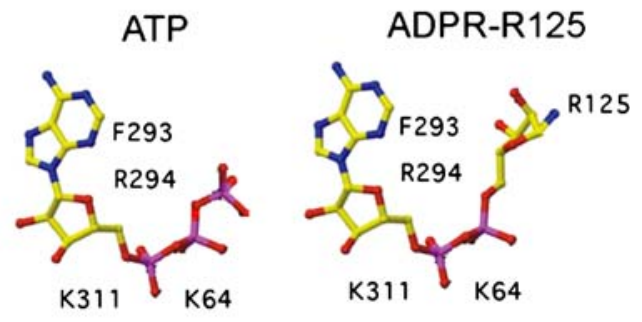

rabbit serum K1G. Moreover, recent reports indicate that mutation of other residues in this region can result in gainof-function P2X7 (A127K in mouse P2X7 and H155Y in human P2X7) [59, 60] or affect the inhibition of P2X7 function by zinc and magnesium (H130A in rat P2X7) [61] (see also Fig. 6, below).

Comparison of the P2X7 mutants analyzed here with those of other $\mathrm{P} 2 \mathrm{X}$ receptors

Table 1 provides a comparison of the mouse P2X7 mutants analyzed in the present study with those of previous mutagenesis studies on other $\mathrm{P} 2 \mathrm{X}$ receptors (summarized in $[6,7,62])$. The only arginine that, when mutated, impairs
ATP potency in all $\mathrm{P} 2 \mathrm{X}$ receptors analyzed so far is residue R294. Mutation of the corresponding residues in human P2X1 (R292) and in rat P2X2 (R291) also resulted in dramatic reduction in ATP potency $[51,52]$. This residue forms part of a conserved NFR motif found in all P2X receptors and has been proposed to coordinate the adenosine and ribose moieties [6]. The results of a recent, elegant mutagenesis study with rat P2X1 strongly indicate that this motif lies at the interface of two adjacent receptor subunits near the ATP-binding site: simultaneous cysteine substitutions of the corresponding phenylalanine residue (F291) and lysine 68 (corresponding to K64 of P2X7 see Fig. 5) allowed the formation of an intersubunit disulfide bond, which was inhibited by ATP [63].

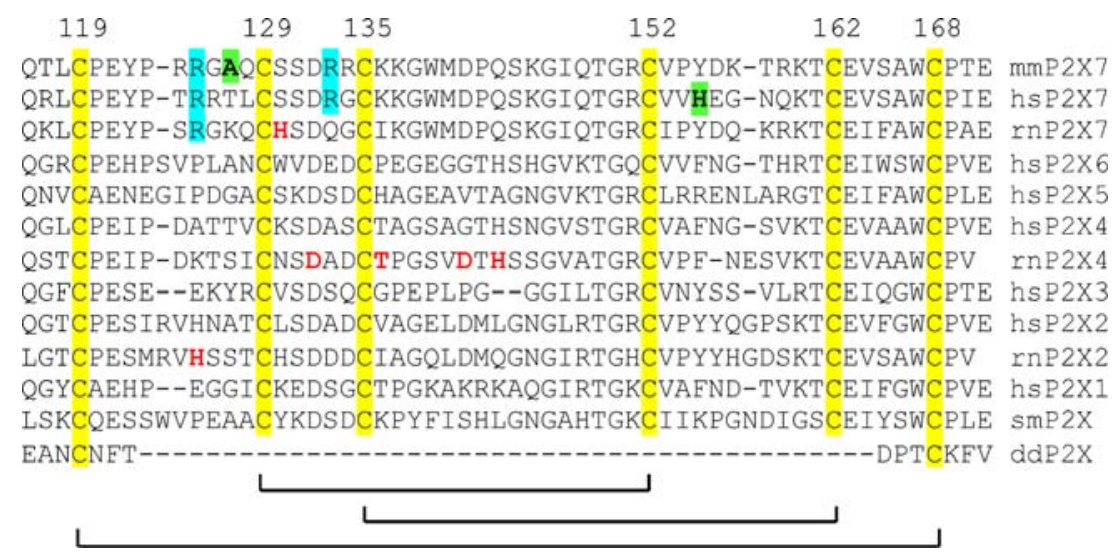

Fig. 6 Summary of mutagenesis data for P2X receptors in the region of the cysteine-rich finger. The arginine residues that serve as targets for ADP-ribosylation in mouse P2X7 [23], rat, and human P2X7 (our own unpublished observations) are highlighted in cyan. Conserved cysteine residues are highlighted in yellow. Amino acid residues that, when mutated, result in a gain-of-function are shown in bold and are highlighted in green $[59,60]$. Residues that alter the sensitivity of the receptor to zinc, copper, and/or magnesium are shown in bold red [58, $59,61,77]$. The positions of the cysteines (numbering for mouse $\mathrm{P} 2 \mathrm{X} 7$ ) are indicated on top, the proposed connectivity [6] is indicated below. $\mathrm{mm}=$ Mus musculus, $\mathrm{hs}=$ Homo sapiens, $\mathrm{rn}=$ Rattus norvegicus, $\mathrm{sm}=$ Schistosoma mansoni, $\mathrm{dd}=$ Dictyostelium discoideum 
Table 1 Summary of mutant phenotypes

\begin{tabular}{|c|c|c|c|c|}
\hline \multicolumn{5}{|c|}{ Residues corresponding to those analyzed in this study } \\
\hline $\mathrm{mP} 2 \mathrm{X} 7$ & $\mathrm{hP} 2 \mathrm{X} 7$ & hP2X1 & $\mathrm{rP} 2 \mathrm{X} 2$ & $\mathrm{rP} 2 \mathrm{X} 4$ \\
\hline$R 53 K$ & $\mathrm{R} 53$ & $\mathrm{~T} 57$ & D57 & E56 \\
\hline$R 125 K$ & $\mathrm{R} 125$ & G123 & $H 120 A$ & A122 \\
\hline$R 151 K$ & $\mathrm{R} 151$ & K148 & H146 & R148 \\
\hline$R 178 K$ & $\mathrm{R} 178$ & R175 & N173 & Q175 \\
\hline$\underline{R 206 K}$ & R206 & $R 202 A$ & K200 & K203 \\
\hline$R 230 K$ & $\mathrm{R} 230$ & Q231 & $K 228 A$ & $\mathrm{R} 231$ \\
\hline$\underline{R 276 K}$ & R276H & $\mathrm{H} 277$ & $\mathrm{R} 274$ & $\mathrm{R} 277$ \\
\hline$\underline{R 277 K}$ & $\mathrm{R} 277$ & G278 & $\mathrm{R} 275$ & $R 278 K$ \\
\hline R294K & R294 & R292A & R290A & R295 \\
\hline R307K & R307Q & $R 305 \mathrm{~A}$ & R304A & R309 \\
\hline$R 316 K$ & $\mathrm{R} 316$ & $R 314 A$ & $\mathrm{R} 313$ & $R 318 K$ \\
\hline \multicolumn{5}{|c|}{ Other positively charged residues with altered ATP potency } \\
\hline K64 & K64 & K68A & K69A & K67 \\
\hline K66 & K66 & K70A & K71A & K69 \\
\hline K193 & K193A & K190A & K188A & K190R \\
\hline K311 & K311A & K309A & K308A & K313 \\
\hline
\end{tabular}

Italics mutants with no or only small changes in ATP sensitivity, bold mutants with strongly reduced ATP potency, bold italics and underlined gain-of-function mutants, upright (without emphasis) residues that to our knowledge have not been tested by mutagenesis. References for: human P2X7 [53, 60, 74], human P2X1 [51], rat $\mathrm{P} 2 \mathrm{X} 2[52,64,75]$, and rat $\mathrm{P} 2 \mathrm{X} 4$ [65]

Other arginine mutants, evidently, affect only certain members of the P2X family. For example, mutation of the residue corresponding to R307 (which seems to be essential for the stability and cell surface expression of mouse P2X7) resulted in a loss of function of human P2X7 (R307Q) and of ratP2X2 (R304A), but not of human P2X1 (R305A) [52, 53]. Mutation of the residue corresponding to R316 (which impaired cell surface expression but not ATP potency of mouse P2X7, see above) did not affect the ATP potency of human P2X1 (R314A) [51]. Mutation of residue R230 to K or A did not affect the function of mouse P2X7, whereas mutation of the corresponding residues (K228A) moderately impaired the ATP potency of rat P2X2 [64].

At the position corresponding to the R206K gain-offunction mutant of mouse P2X7, human P2X1 (R202) and $\mathrm{hP} 2 \mathrm{X} 7$ (R206) also carry an arginine residue, while hP2X2 (K200) and hP2X4 (K203) carry a lysine residue. Mutation of R202 did not affect the ATP potency of human P2X1 [51]. The arginine doublet at the other two gain-of-function mutants of mouse P2X7 (R276, R277) is conserved in rat P2X2 (R274/ R275), rat P2X4 (R277/R278), and human P2X7 (R276/ R277), but not in human P2X1 (H277/G278). Mutation of the downstream arginine residue in this doublet in rat P2X4 resulted either in a slightly enhanced ATP potency (R278K) or in a dramatically reduced in ATP potency (R278A) [65].
The arginine residues in the cysteine-rich finger of mouse P2X7, which serve as targets for ADP-ribosylation in mouse $\mathrm{P} 2 \mathrm{X} 7$, are only partially conserved in rat and human P2X7, where they also function as targets for ADP-ribosylation (our own unpublished observations). However, these residues are conserved neither in other mammalian P2X receptors nor in the distant P2X orthologs of Schistosoma mansoni $[66,67]$ and Dictyostelium discoideum (Fig. 6). Note that the distal portion of the finger is missing in the Dictyostelium P2X, recently shown to be expressed in an intracellular organelle (the contractile vacuole) where it plays a crucial role in cell volume regulation [68]. The absence of suitable targets for ADP-ribosylation in other P2X receptors indicates that gating by ADP-ribosylation is unique to P2X7. It is tempting to speculate that there may be an evolutionary link between the comparatively low sensitivity of P2X7 to gating by the soluble ligand ATP and its unique capacity to be gated by a covalently tethered ligand.

\section{Materials and methods}

Cloning of expression vectors and cell transfections

Expression vectors for wild-type ART2.2 and wild-type or mutant P2X7 were cloned as described previously [23, 6971]. The expression construct for monomeric red fluorescent protein (mRFP) was from Clontech. Expression constructs ( $5 \mu \mathrm{g}$ per $10^{6}$ cells) were transfected into HEK cells with the jet PEI transfection reagent (Q-Biogen). Anti-P2X7 antibodies were generated by genetic immunization as described previously [50, 71]. Antibodies were conjugated to Alexa488 according to the manufacturer's (Molecular Probes/ Invitrogen) instructions.

\section{FACS analyses}

Cells were harvested by trypsinization $20 \mathrm{~h}$ post-transfection, followed by staining with Alexa-488-conjugated antibodies $\left(0.2 \mu \mathrm{g} / 2 \times 10^{5}\right.$ cells $\left./ 100 \mu \mathrm{l}\right)$. Separate aliquots of cells were washed and then incubated in the absence or presence of the indicated concentrations of ATP in $10 \mathrm{mM}$ HEPES $\mathrm{pH} 7.5,140 \mathrm{mM} \mathrm{NaCl}, 5 \mathrm{mM} \mathrm{KCl}, 10 \mathrm{mM}$ glucose for $60 \mathrm{~min}$ at $37^{\circ} \mathrm{C}$. Cells were washed before FACS analyses using a FACS-Calibur and the Cellquest-Pro software (Becton Dickinson).

\section{Calcium imaging by fluorescence microscopy}

For ratiometric calcium imaging [72, 73], HEK cells were co-transfected with expression vectors for P2X7, ART2.2, and mRFP as indicated and plated at low density on glass bottom culture dishes (35 mm, MatTek, Ashland, USA). 
Twenty hours post-transfection, the culture medium was removed gently and replaced with prewarmed buffer (15 mM HEPES, pH 7.4, $140 \mathrm{mM} \mathrm{NaCl}, 5 \mathrm{mM} \mathrm{KCl}$, $1 \mathrm{mM} \mathrm{MgCl} 2,1.35 \mathrm{mM} \mathrm{CaCl}, 10 \mathrm{mM}$ glucose, $0.1 \%$ BSA), containing $4 \mu \mathrm{M}$ Fura-2/AM (Calbiochem) for $30 \mathrm{~min}$ at $37^{\circ} \mathrm{C}$. Imaging of cells was performed with a Leica DM-IRBE fluorescence microscope equipped with perfusion system (Warner Instruments, Hamden, USA) and a $40 \times$ objective (1.3 numerical aperture). Cells were continuously perfused with prewarmed $\left(37^{\circ} \mathrm{C}\right)$ buffer (see above) containing the indicated concentrations of ATP or NAD. Alternating excitation at 340 and $380 \mathrm{~nm}$ was achieved using a monochromator system (Polychrome II; TILL Photonics, Graefelfing, Germany). Two images were acquired every $5 \mathrm{~s}$ with a grayscale CCD camera (type C4742-95-12NRB; Hamamatsu, Enfield, UK). Raw data images were stored on a hard disc, and ratio images (340/ $380 \mathrm{~nm}$ ) were calculated using Openlab software (v3.09; Improvision, Tübingen, Germany).

Acknowledgments This work was supported by grants from the Deutsche Forschungsgemeinschaft (grants No. 310/6 and 310/8 to FKN and FH; grants GU 360/7 and 360/9 to AHG). SA was the recipient of stipends from the Fondation pour la Recherche Médicale and from the Deutsche Forschungsgemeinschaft. We thank Fenja Braasch, Gudrun Dubberke, and Fabienne Seyfried, Hamburg, for excellent technical assistance. FKN, FH, MS, and AHG designed and supervised this study. SA cloned the P2X7 mutants and performed the experiments shown in Fig. 3, NS and RF performed the experiments shown in Figs. 2 and 4. FKN wrote the paper. We thank Drs. Bernhard Fleischer, Hans-Willi Mittrücker, and Roland Martin, Hamburg, and Dr. Olivier Boyer, Rouen, for critical reading of the manuscript.

Open Access This article is distributed under the terms of the Creative Commons Attribution Noncommercial License which permits any noncommercial use, distribution, and reproduction in any medium, provided the original author(s) and source are credited.

\section{References}

1. Ziegler M (2000) New functions of a long-known molecule. Emerging roles of NAD in cellular signaling. Eur $\mathrm{J}$ Biochem 267:1550-1564

2. la Sala A, Ferrari D, Di Virgilio F, Idzko M, Norgauer J, Girolomoni G (2003) Alerting and tuning the immune response by extracellular nucleotides. J Leukoc Biol 73:339-343

3. Khakh BS, North RA (2006) P2X receptors as cell-surface ATP sensors in health and disease. Nature 442:527-532

4. Di Virgilio F, Chiozzi P, Ferrari D, Falzoni S, Sanz JM, Morelli A, Torboli M, Bolognesi G, Baricordi OR (2001) Nucleotide receptors: an emerging family of regulatory molecules in blood cells. Blood 97:587-600

5. North RA (2002) Molecular physiology of P2X receptors. Physiol Rev 82:1013-1067

6. Vial C, Roberts JA, Evans RJ (2004) Molecular properties of ATP-gated P2X receptor ion channels. Trends Pharmacol Sci 25:487-493
7. Stojilkovic SS, Tomic M, He ML, Yan Z, Koshimizu TA, Zemkova H (2005) Molecular dissection of purinergic P2X receptor channels. Ann N Y Acad Sci 1048:116-130

8. Corda D, Di Girolamo M (2003) Functional aspects of protein mono-ADP-ribosylation. EMBO J 22:1953-1958

9. Koch-Nolte F, Adriouch S, Bannas P, Krebs C, Scheuplein F, Seman M, Haag F (2006) ADP ribosylation of membrane proteins: unveiling the secrets of a crucial regulatory mechanism in mammalian cells. Ann Med 38:188-199

10. Zolkiewska A (2005) Ecto-ADP-ribose transferases: cell-surface response to local tissue injury. Physiology (Bethesda) 20:374-381

11. Robson SC, Sevigny J, Zimmermann H (2006) The E-NTPDase family of ectonucleotidases: structure-function relationships and pathophysiological significance. Purinergic Signal 2:409-430

12. Krebs C, Adriouch S, Braasch F, Koestner W, Leiter EH, Seman M, Lund FE, Oppenheimer N, Haag F, Koch-Nolte F (2005) CD38 controls ADP-ribosyltransferase-2-catalyzed ADP ribosylation of T cell surface proteins. J Immunol 174:3298-3305

13. Nemoto E, Yu Y, Dennert G (1996) Cell surface ADPribosyltransferase regulates lymphocyte function-associated molecule-1 (LFA-1) function in T cells. J Immunol 157:3341-3349

14. Paone G, Wada A, Stevens LA, Matin A, Hirayama T, Levine RL, Moss J (2002) ADP ribosylation of human neutrophil peptide-1 regulates its biological properties. Proc Natl Acad Sci U S A 99:8231-8235

15. Seman M, Adriouch S, Scheuplein F, Krebs C, Freese D, Glowacki G, Deterre P, Haag F, Koch-Nolte F (2003) NAD-induced T cell death: ADP-ribosylation of cell surface proteins by ART2activates the cytolytic P2X7 purinoceptor. Immunity 19:571-582

16. Koch-Nolte F, Reche P, Haag F, Bazan F (2001) ADPribosyltransferases: plastic tools for inactivating protein and small molecular weight targets. J Biotechnol 92:81-87

17. Mueller-Dieckmann C, Ritter H, Haag F, Koch-Nolte F, Schulz G (2002) Structure of the ecto-ADP-ribosyl transferase ART2.2 from rat. J Mol Biol 322:687-696

18. Han S, Craig JA, Putnam CD, Carozzi NB, Tainer JA (1999) Evolution and mechanism from structures of an ADP-ribosylating toxin and NAD complex. Nat Struct Biol 6:932-936

19. Han S, Arvai AS, Clancy SB, Tainer JA (2001) Crystal structure and novel recognition motif of rho ADP-ribosylating C3 exoenzyme from Clostridium botulinum: structural insights for recognition specificity and catalysis. J Mol Biol 305:95-107

20. Schleberger C, Hochmann H, Barth H, Aktories K, Schulz GE (2006) Structure and action of the binary $\mathrm{C} 2$ toxin from Clostridium botulinum. J Mol Biol 364:705-715

21. Aktories K, Barmann M, Ohishi I, Tsuyama S, Jakobs KH, Habermann E (1986) Botulinum C2 toxin ADP-ribosylates actin. Nature 322:390-392

22. Jorgensen R, Merrill AR, Yates SP, Marquez VE, Schwan AL, Boesen T, Andersen GR (2005) Exotoxin A-eEF2 complex structure indicates ADP ribosylation by ribosome mimicry. Nature 436:979-984

23. Adriouch S, Bannas P, Schwarz N, Fliegert R, Guse AH, Seman M, Haag F, Koch-Nolte F (2008) ADP-ribosylation at R125 gates the P2X7 ion channel by presenting a covalent ligand to its nucleotide binding site. FASEB J 22:861-869

24. Perregaux D, Gabel CA (1994) Interleukin-1 beta maturation and release in response to ATP and nigericin. Evidence that potassium depletion mediated by these agents is a necessary and common feature of their activity. J Biol Chem 269:15195-15203

25. Ferrari D, Chiozzi P, Falzoni S, Dal Susino M, Melchiorri L, Baricordi OR, Di Virgilio F (1997) Extracellular ATP triggers IL1 beta release by activating the purinergic $\mathrm{P} 2 \mathrm{Z}$ receptor of human macrophages. J Immunol 159:1451-1458

26. Solle M, Labasi J, Perregaux DG, Stam E, Petrushova N, Koller BH, Griffiths RJ, Gabel CA (2001) Altered cytokine production in mice lacking P2X(7) receptors. J Biol Chem 276:125-132 
27. MacKenzie A, Wilson HL, Kiss-Toth E, Dower SK, North RA, Surprenant A (2001) Rapid secretion of interleukin-1beta by microvesicle shedding. Immunity 15:825-835

28. Gudipaty L, Munetz J, Verhoef PA, Dubyak GR (2003) Essential role for $\mathrm{Ca} 2+$ in regulation of IL-1beta secretion by $\mathrm{P} 2 \mathrm{X} 7$ nucleotide receptor in monocytes, macrophages, and HEK-293 cells. Am J Physiol Cell Physiol 285:C286-299

29. Ferrari D, Pizzirani C, Adinolfi E, Lemoli RM, Curti A, Idzko M, Panther E, Di Virgilio F (2006) The P2X7 receptor: a key player in IL-1 processing and release. J Immunol 176:3877-3883

30. Chiozzi P, Sanz JM, Ferrari D, Falzoni S, Aleotti A, Buell GN, Collo G, Di Virgilio F (1997) Spontaneous cell fusion in macrophage cultures expressing high levels of the P2Z/P2X7 receptor. J Cell Biol 138:697-706

31. Lammas DA, Stober C, Harvey CJ, Kendrick N, Panchalingam S, Kumararatne DS (1997) ATP-induced killing of mycobacteria by human macrophages is mediated by purinergic $\mathrm{P} 2 \mathrm{Z}(\mathrm{P} 2 \mathrm{X} 7)$ receptors. Immunity 7:433-444

32. Coutinho-Silva R, Stahl L, Raymond MN, Jungas T, Verbeke P, Burnstock G, Darville T, Ojcius DM (2003) Inhibition of chlamydial infectious activity due to P2X7R-dependent phospholipase D activation. Immunity 19:403-412

33. Gu B, Bendall LJ, Wiley JS (1998) Adenosine triphosphateinduced shedding of CD23 and L-selectin (CD62L) from lymphocytes is mediated by the same receptor but different metalloproteases. Blood 92:946-951

34. Zanovello P, Bronte V, Rosato A, Pizzo P, Di Virgilio F (1990) Responses of mouse lymphocytes to extracellular ATP. II. Extracellular ATP causes cell type-dependent lysis and DNA fragmentation. J Immunol 145:1545-1550

35. Kawamura H, Aswad F, Minagawa M, Malone K, Kaslow H, Koch-Nolte F, Schott WH, Leiter EH, Dennert G (2005) P2X7 receptor-dependent and -independent $\mathrm{T}$ cell death is induced by nicotinamide adenine dinucleotide. J Immunol 174:1971-1979

36. Sutterwala FS, Ogura Y, Szczepanik M, Lara-Tejero M, Lichtenberger GS, Grant EP, Bertin J, Coyle AJ, Galan JE, Askenase PW, Flavell RA (2006) Critical role for NALP3/CIAS1/Cryopyrinin innate and adaptive immunity through its regulation of caspase-1. Immunity 24:317-327

37. Mariathasan S, Weiss DS, Newton K, McBride J, O'Rourke K, Roose-Girma M, Lee WP, Weinrauch Y, Monack DM, Dixit VM (2006) Cryopyrin activates the inflammasome in response to toxins and ATP. Nature 440:228-232

38. Di Virgilio F (2007) Liaisons dangereuses: $P 2 X(7)$ and the inflammasome. Trends Pharmacol Sci 8:465-472

39. Nuttle LC, Dubyak GR (1994) Differential activation of cation channels and non-selective pores by macrophage $\mathrm{P} 2 \mathrm{z}$ purinergic receptors expressed in Xenopus oocytes. J Biol Chem 269:1398813996

40. Surprenant A, Rassendren F, Kawashima E, North RA, Buell G (1996) The cytolytic P2Z receptor for extracellular ATP identified as a $\mathrm{P} 2 \mathrm{X}$ receptor $(\mathrm{P} 2 \mathrm{X} 7)$. Science $272: 735-738$

41. Mackenzie AB, Young MT, Adinolfi E, Surprenant A (2005) Pseudoapoptosis induced by brief activation of ATP-gated P2X7 receptors. J Biol Chem 280:33968-33976

42. Elliott JI, Surprenant A, Marelli-Berg FM, Cooper JC, CassadyCain RL, Wooding C, Linton K, Alexander DR, Higgins CF (2005) Membrane phosphatidylserine distribution as a non-apoptotic signalling mechanism in lymphocytes. Nat Cell Biol 7:808-816

43. Steinberg TH, Newman AS, Swanson JA, Silverstein SC (1987) ATP4- permeabilizes the plasma membrane of mouse macrophages to fluorescent dyes. J Biol Chem 262:8884-8888

44. Smart ML, Gu B, Panchal RG, Wiley J, Cromer B, Williams DA, Petrou S (2003) P2X7 receptor cell surface expression and cytolytic pore formation are regulated by a distal C-terminal region. J Biol Chem 278:8853-8860
45. Pelegrin P, Surprenant A (2006) Pannexin-1 mediates large pore formation and interleukin-1beta release by the ATP-gated P2X7 receptor. EMBO J 25:5071-5082

46. Nicke A, Baumert HG, Rettinger J, Eichele A, Lambrecht G, Mutschler E, Schmalzing G (1998) P2X1 and P2X3 receptors form stable trimers: a novel structural motif of ligand-gated ion channels. EMBO J 17:3016-3028

47. Clyne JD, Wang LF, Hume RI (2002) Mutational analysis of the conserved cysteines of the rat P2X2 purinoceptor. J Neurosci 22:3873-3880

48. Ennion SJ, Evans RJ (2002) Conserved cysteine residues in the extracellular loop of the human P2X(1) receptor form disulfide bonds and are involved in receptor trafficking to the cell surface. Mol Pharmacol 61:303-311

49. McGuffin LJ, Bryson K, Jones DT (2000) The PSIPRED protein structure prediction server. Bioinformatics 16:404-405

50. Adriouch S, Dubberke G, Diessenbacher P, Rassendren F, Seman M, Haag F, Koch-Nolte F (2005) Probing the expression and function of the $\mathrm{P} 2 \mathrm{X} 7$ purinoceptor with antibodies raised by genetic immunization. Cell Immunol 236:72-77

51. Ennion S, Hagan S, Evans RJ (2000) The role of positively charged amino acids in ATP recognition by human P2X(1) receptors. J Biol Chem 275:29361-29367

52. Jiang LH, Rassendren F, Surprenant A, North RA (2000) Identification of amino acid residues contributing to the ATPbinding site of a purinergic P2X receptor. J Biol Chem 275:3419034196

53. Gu BJ, Sluyter R, Skarratt KK, Shemon AN, Dao-Ung LP, Fuller SJ, Barden JA, Clarke AL, Petrou S, Wiley JS (2004) An Arg307 to Gln polymorphism within the ATP-binding site causes loss of function of the human P2X7 receptor. J Biol Chem 279:3128731295

54. Moreschi I, Bruzzone S, Nicholas RA, Fruscione F, Sturla L, Benvenuto F, Usai C, Meis S, Kassack MU, Zocchi E, De Flora A (2006) Extracellular NAD + is an agonist of the human $\mathrm{P} 2 \mathrm{Y} 11$ purinergic receptor in human granulocytes. J Biol Chem 281:31419-31429

55. Kim M, Jiang LH, Wilson HL, North RA, Surprenant A (2001) Proteomic and functional evidence for a $\mathrm{P} 2 \mathrm{X} 7$ receptor signalling complex. EMBO J 20:6347-6358

56. Bannas P, Adriouch S, Kahl S, Braasch F, Haag F, Koch-Nolte F (2005) Activity and specificity of toxin-related mouse T cell ectoADP-ribosyltransferase ART2.2 depends on its association with lipid rafts. Blood 105:3663-3670

57. Aswad F, Kawamura H, Dennert G (2005) High sensitivity of $\mathrm{CD} 4+\mathrm{CD} 25+$ regulatory $\mathrm{T}$ cells to extracellular metabolites nicotinamide adenine dinucleotide and ATP: a role for P2X7 receptors. J Immunol 175:3075-3083

58. Nagaya N, Tittle RK, Saar N, Dellal SS, Hume RI (2005) An intersubunit zinc binding site in rat $\mathrm{P} 2 \mathrm{X} 2$ receptors. J Biol Chem 280:25982-25993

59. Young MT, Pelegrin P, Surprenant A (2007) Amino acid residues in the P2X7 receptor that mediate differential sensitivity to ATP and BzATP. Mol Pharmacol 71:92-100

60. Cabrini G, Falzoni S, Forchap SL, Pellegatti P, Balboni A, Agostini P, Cuneo A, Castoldi G, Baricordi OR, Di Virgilio F (2005) A His-155 to Tyr polymorphism confers gain-of-function to the human $\mathrm{P} 2 \mathrm{X} 7$ receptor of human leukemic lymphocytes. J Immunol 175:82-89

61. Acuna-Castillo C, Coddou C, Bull P, Brito J, Huidobro-Toro JP (2007) Differential role of extracellular histidines in copper, zinc, magnesium and proton modulation of the $\mathrm{P} 2 \mathrm{X} 7$ purinergic receptor. J Neurochem 101:17-26

62. North RA, Surprenant A (2000) Pharmacology of cloned P2X receptors. Annu Rev Pharmacol Toxicol 40:563-580

63. Marquez-Klaka B, Rettinger J, Bhargava Y, Eisele T, Nicke A (2007) Identification of an intersubunit cross-link between 
substituted cysteine residues located in the putative ATP binding site of the P2X1 receptor. J Neurosci 27:1456-1466

64. Nakazawa K, Ojima H, Ishii-Nozawa R, Takeuchi K, Ohno Y (2004) Amino acid substitutions from an indispensable disulfide bond affect P2X2 receptor activation. Eur J Pharmacol 483:29-35

65. Yan Z, Liang Z, Tomic M, Obsil T, Stojilkovic SS (2005) Molecular determinants of the agonist binding domain of a P2X receptor channel. Mol Pharmacol 67:1078-1088

66. Agboh KC, Webb TE, Evans RJ, Ennion SJ (2004) Functional characterization of a $\mathrm{P} 2 \mathrm{X}$ receptor from Schistosoma mansoni. J Biol Chem 279:41650-41657

67. Raouf R, Blais D, Seguela P (2005) High zinc sensitivity and pore formation in an invertebrate $\mathrm{P} 2 \mathrm{X}$ receptor. Biochim Biophys Acta 1669:135-141

68. Fountain SJ, Parkinson K, Young MT, Cao L, Thompson CR, North RA (2007) An intracellularP2X receptor required for osmoregulation in Dictyostelium discoideum. Nature 448:200-203

69. Koch-Nolte F, Duffy T, Nissen M, Kahl S, Killeen N, Ablamunits V, Haag F, Leiter EH (1999) A new monoclonal antibody detects a developmentally regulated mouse ecto-ADP-ribosyltransferase on T cells: subset distribution, inbred strain variation, and modulation upon T cell activation. J Immunol 163:6014-6022

70. Adriouch S, Dox C, Welge V, Seman M, Koch-Nolte F, Haag F (2002) Cutting edge: a natural P451L mutation in the cytoplasmic domain impairs the function of the mouse $\mathrm{P} 2 \mathrm{X} 7$ receptor. $\mathrm{J}$ Immunol 169:4108-4112
71. Möller M, Jung C, Adriouch S, Dubberke G, Seyfried F, Seman M, Haag F, Koch-Nolte F (2007) Monitoring the expression of purinoceptors and nucleotide-metabolizing ecto-enzymes with antibodies directed against proteins in native conformation. Purinergic Signal 3:359-366

72. Kunerth S, Mayr GW, Koch-Nolte F, Guse AH (2003) Analysis of subcellular calcium signals in T-lymphocytes. Cell Signal 15: 783-792

73. Gasser A, Glassmeier G, Fliegert R, Langhorst MF, Meinke S, Hein D, Kruger S, Weber K, Heiner I, Oppenheimer N, Schwarz JR, Guse AH (2006) Activation of T cell calcium influx by the second messenger ADP-ribose. J Biol Chem 281:2489-2496

74. Worthington RA, Smart ML, Gu BJ, Williams DA, Petrou S, Wiley JS, Barden JA (2002) Point mutations confer loss of ATP-induced human $\mathrm{P} 2 \mathrm{X}(7)$ receptor function. FEBS Lett 512:43-46

75. Clyne JD, LaPointe LD, Hume RI (2002) The role of histidine residues in modulation of the rat $\mathrm{P} 2 \mathrm{X}(2)$ purinoceptor by zinc and pH. J Physiol 539:347-359

76. Evans RJ (2008) Orthosteric and allosteric binding sites of P2X receptors. Eur Biophys J 38:319-327

77. Coddou C, Acuna-Castillo C, Bull P, Huidobro-Toro JP (2007) Dissecting the facilitator and inhibitor allosteric metal sites of the P2X4 receptor channel: critical roles of CYS132 for zinc potentiation and ASP138 for copper inhibition. J Biol Chem 282:36879-36886 